\title{
ECONOMIC EFFECTIVENESS OF URBAN RAILWAY INFRASTRUCTURE INVESTMENTS IN THE LIGHT OF GLOBALIZATION AND REGIONAL DEVELOPMENT. STUDY ON EXAMPLE OF POMERANIAN METROPOLITAN RAILWAY CONSTRUCTION
}

\begin{abstract}
The myth of a borderless world pillars of open markets - the USA and the UKare wobbling, and China is positioning itself as globalization staunchest defender. But is a mass retreat from globalization really the right approach for companies in these uncertain times? Or short of packing up and returning home, should they focus on localization - that is producing or even innovating where they sell-as the strategy of choice? Recall that as recently as a decade ago, business leaders and politicians believed that the world and that global companies, unconstrained by countries borders, would soon dominate the world economy. Today's turmoil calls for a more subtle reworking of multinationals' strategies organizational structures, and approaches to societal engagement. Poland has already been a beneficent of EU funds. Actually Polish internal indebtedness is increasing and Poland will not be able to use EU funds in the future.

The authors would like to present the Polish issue of planning investments financed by EU funds, e.g. the project of the Pomeranian Metropolitan Railway. Construction of this railroad is the first successful project in Poland to build a new railroad since the transformation of the state system in 1989. The project was financed by the European Regional Development Fund. The decision to build the line and award the grant was made on the basis of a feasibility study. A key element of this document was the CBA analysis, which was carried out on the basis of the Blue Book for railway transport.

A narrow look at the economic aspects and the earlier underestimated costs of the investment caused that the investment is unfinished. The question should
\end{abstract}


be asked is whether use of another method of economic analysis would help to complete this investment without the need for over a dozen years of staging investment expenditures? Difficulties with the economic efficiency account are similar to the barriers to the development of globalization.

Keywords: globalization, regional development, feasibility study, Pomeranian Metropolitan Railway, Wider Economic Impact

\section{Introduction}

Urban rail transport has great carriage potential. In 2015 in Beijing there were 3.32 billion trips using urban rail transport e.i. around 9.11 million trips per day. It constitutes approximately $45 \%$ of the total trips from all kinds of transportation (Sun, 2018).

In connection with the debt of China's economy caused by inappropriately granted (unpaid) China bank loans which enter the capital market and the state begins to use its tools, which include stock exchange and their papers, especially bonds (sovereign debt funds), which are invested in infrastructure. Debt papers are safer than equities because they are guaranteed by national budgets, which are noted by the rating agencies.

China's investments are beginning to be financed from other sources than bank loans. The first new source of financing for investments are stock exchange shares (International investors chase the red dragon, 2017).

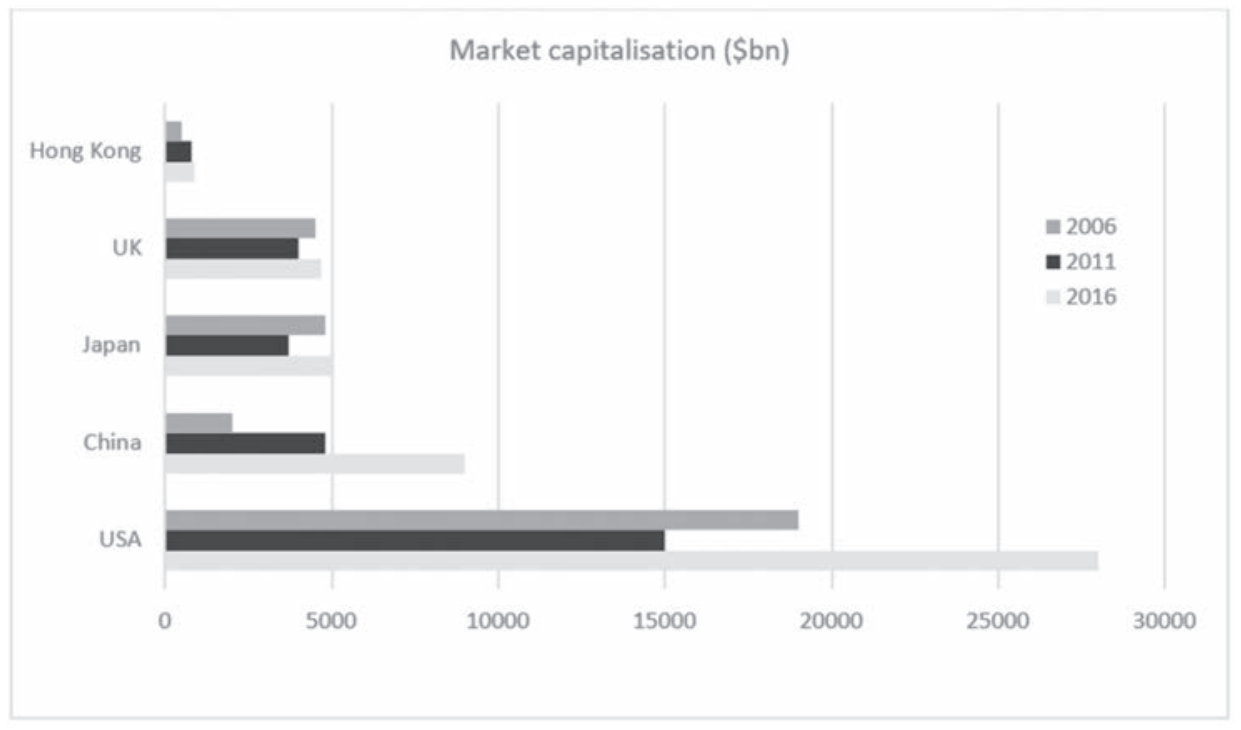

Figure 1. The growth of Chinese equities in the global investment landscape

Surce: (International investors chase the red dragon, 2017) 
Another source are bank debt securities, which China primarily finance investments related to environmental protection (green bond issues). In recent years, the level of green bond issues in China has reached a similar level to France. Figure 2 presents the comparison of the biggest green bond issuers.

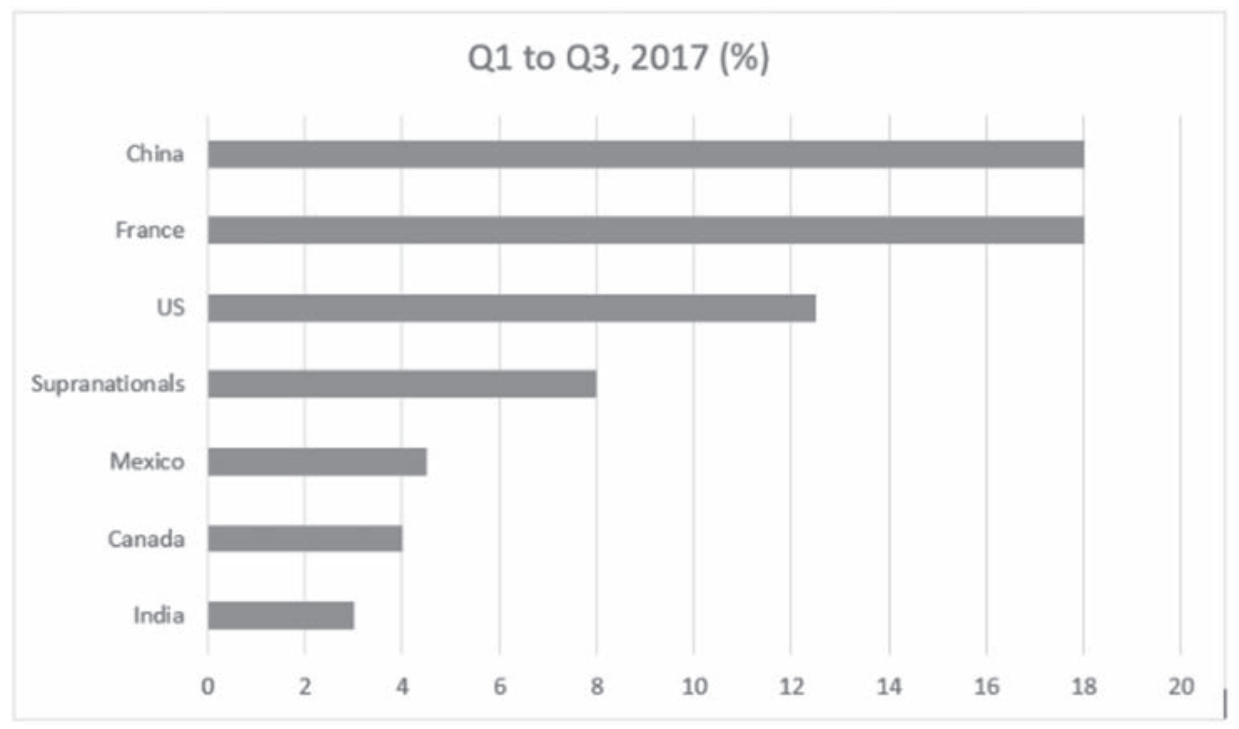

Figure 2. Biggest green bond issuers

Source: (Refinance push China's ethical bond issuance takes it to top spot in world green paper league, 2017)

Since 2015, China has been securing green bond issues from three sources: financial institutions, companies and structure finance. The structure of green bond issues financing is shown in Figure 3.

China is becoming an important player in the global investment market. For European countries, it has become an important partner with high financial potential. Developing countries of Central Asia and Eastern Europe can use those opportunities to implement many infrastructure investments. Also for European Union countries, China's capital is becoming an important alternative to European funds. European funds face the challenge of Brexit, beneficial for both sides. It is doubtful whether the issue of agreement on the exit of Great Britain from the EU will be successful before the deadline of March 15, 2019 (Wobbling into the WTO, 2017). How will the new limited funds be divided by the EU Finance Ministry for the euro zone countries and for the countries outside this zone? 


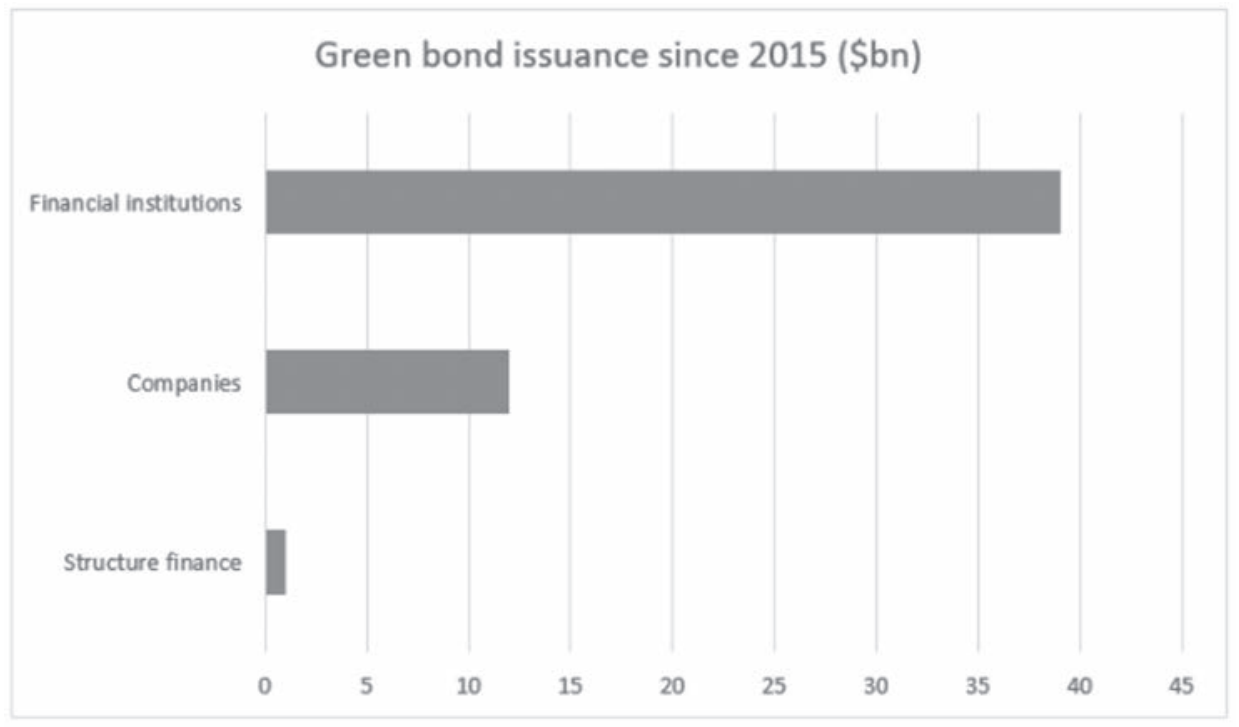

Figure 3. China's banks lead the field

Source: (Refinance push China's ethical bond issuance takes it to top spot in world green paper league, 2017)

\section{Challenges for globalization and regional development}

The Chinese economy has entered "a new normal" characterized by slower and steadier growth, which is driven mainly by consumption rather than investment and trade. Doubts about the future of globalization began to surface during the 2008-2009 financial crisis. As a result China's GDP fell to 6,4\%. In 2017 China's GDP stood at 6,9\% But as macroeconomic condition improved the gloom gave way to a murky mix of perspective.

In the face of such ambiguity, it is essential to look at the data. The two index components of business interest merchandise trade were hit hard during the financial crisis, but neither has suffered a similar decline since then.

It is the kind of company that for years was a safer bet for investors. China City Construction is a big government owned company and focused on building basic infrastructures. But it turned out the bet was not so safer after all. In November 2017 China City missed interest payment on three separate bonds after falling to refinance its hefty debt. A regulatory clean up debts China's markets but not yet its economy. Debt is the biggest of all having climbed in the past decade from $160 \%$ of GDP to naughty $260 \%$ (Chinese finance stormy weather, 2017).

For firms even those closely tied to the state the rise of borrowing costs have been even sleeper than yields on ten-year bond issue by China Development Bank "a policy bank" that finances state project at home and grew to nearly $5 \%$ the highest in three years (Disaster management, 2017). 
Trade experienced a large drop-off in 2015 but was almost entirely a price effect driven by plunging commodity prices and the rising value of the US dollar. The updated data for 2016 showed that factoring in people and information flows is reinforced by the conclusion that foreign direct investment has stayed flat and rapidly increased in China.

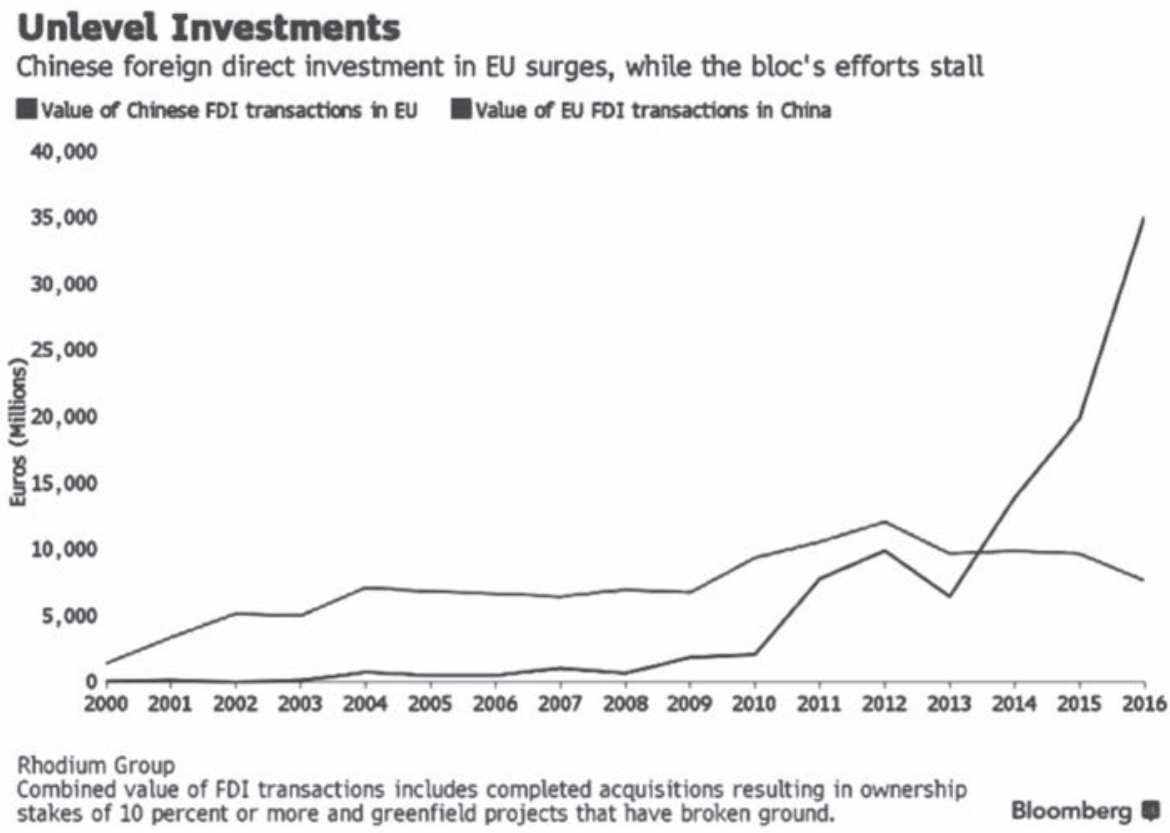

Figure 4. Disparity of FDI in EU and China

Source: (https://www.bloomberg.com/news/articles/2017-07-20/panda-diplomacy-masks-doubtsin-europe-over-china-s-sincerity)

The figure above presents primarily investments in the linear and point infrastructure implemented by Chinese national infrastructure concerns.

From 2013 rapid increase of FDI in China and the decline of European FDI in China should be noted. A huge investment gap was created between Europe and China. It results from infrastructure project 'One Belt, One Road' initiated by the president of China.

The heavily promoted "One Belt, One Road" initiative is, in part, an attempt to develop new markets for China across Eurasia - with infrastructure links across central and south Asia towards Europe and Africa. Twenty Chinese cities are now connected to Europe by direct rail links and the amount of freight sent this way has quintupled since 2013, as routes such as Chengdu to Prague and Wuhan to Lyon established themselves (Rachman, 2017).

China doesn't want to dominate Eurasia countries at foreign trade. It initiates bilateral agreements in foreign trade. Nowadays, it's similar to the current policy of actually American administration, which pulled down multilateral trade 
agreements, e.g. twelve countries Pacific Rims so called Trans Pacific Partnership (TPP). Nevertheless it should be asked if bilateral trade agreements are useful for developing globalization?

Exaggerated perception about the depth of globalization - that is how much activity is international flow versus domestic or regional, come at the cost.

When business people think the world is more globalized than it really is they tend to underestimate the need to understand and respond to differences across countries when operating abroad. In the public policy sphere leaders tend to underestimate the potential gains from additional globalization and to overestimate its harmful consequences for society.

Surveys suggest that people also underestimate the breath of globalization that is the extent to which international activity is distributed. There are two laws that govern respectively, the depth and breath of globalization:

- The law of semi globalization: international business activity, while significant it is much less intense than domestic activity;

- The law of distance: international interactions are dampened by distance along cultural, administrative, geographic and often economic dimensions.

These principles can be counted to apply in the future. Given surging protectionist sentiments and possibly even trade war, will they continue to hold? The best way of stress-testing them at the time when the precise policies of American administration and other governments are still unclear would be a major trade war which could lead to the largest reversal of globalization in history.

Two major lessons, corresponding to the two laws of globalization stand out. The first lesson is that although trade dropped precipitously in the 1930's, it did not dry entirely. The second lesson is about overcoming large distances between states, which led to national protectionism.

Getting back to the future: if global trade didn't screech to hold in the 1930's, it's reasonably to say that it won't in 2020 either.

If cross-border interactions in aggregate are unlikely to fade, what is the rationale for individual multinationals pulling back?

The retreat of global companies has stirred significant discussion, pointed to the performance problems they have experienced. But the declines over the past three to four years occurred in an the environment of plunging commodity prices, dropping demand for globalization related services and for the U.S. companies shifts in exchange rate. All countries that want to get out of public debt are based only on growth in consumption and investments, and disregard foreign trade.

That said, many multinational companies do need to pay renewed attention to where they compete in all major markets, such problems still persist.

Recent data on companies ranked among the top 100 with the most assets located outside their home, their account for about $60 \%$ of their revenues and probably a large slice of their profits. And only a single-digit percentage of the Fortune Global 500 - the world's largest firms by revenue - earn at least $20 \%$ of profits in America, Europe and Asia-Pacific.

Although FDI is less sensitive to geographic distance the trade staying at home is an option. Only about $0,1 \%$ of the world's firms are multinational, which is not a big part of the largest companies. 
The Economist points to a rising cohort of small firms using e-commerce is still significantly less internalized than offline commerce.

And in the light of changes brewing in the political environment this seems like a particularly in specific time to think that one can go global just by setting up a website or joining an online platform. There are three globalization and regional options:

1. Adaptation boosts revenues and market share by tailoring products and services to suite local tastes and needs.

2. Aggregation delivers economies of scale by expanding operations into regional or global market.

3. Arbitrage exploits differences in labour cost, tax regimes and other factors between national and regional market.

China is a two-speed market: old versus new with old sectors such as industry and big banking experiencing a structural slowdown and new consumer-orientated and service companies driving growth (Wang, 2018).

China is currently not looking for export, but for foreign investment in infrastructure. An example of these investments is the "One Belt One Road" project, connecting China with Europe and Africa.

Recipients of China's foreign direct investment (FDI) are afraid that state-owned infrastructure companies will export public debt to their countries.

The growing sophistication of the China's economy will challenge western assumption that American and European companies can continue to dominate the high-tech economy, leaving China to concentrate on the lower end of the value chain. China's emergence as a major exporter of capital also means that its companies will inevitably increase their presence as owners of physical and intellectual assets in the west (Kołodko, 2008).

The economy came out of the crisis, but it is still globally indebted \$135tn (IMF warns of 'vulnerabilities' that could derail global recovery, 2017). Investors are beginning to fear spending investment funds despite low interest rates on loans.

Currently, there are favourable conditions on the market for the implementation of transport infrastructure investments, which are characterized by low financial efficiency and a long payback period.

This is the exact opposite of real estate development investments related to housing construction (e.g. mortages). Investments in transport infrastructure will not affect the formation of a financial bubble.

\section{A comparative study of the neoclassic cba approach with wider economic impact at the example of Polish railway projects}

The investment process in the linear and point infrastructure in the European Union countries continues. Part of the investment has been completed, some is in the implementation phase. Many investments are also in the preparation phase and their implementation is planned before 2020. In Poland, the investment process in infrastructure is regulated by strategic government and local government 
documents. In rail transport, it is the National Railway Program (2016), covering all the planned investments. In road transport, the main strategic document is the National Road Construction Program. The process of planning investments in railway infrastructure starts with defining the project. Then a feasibility study is carried out, analyzing the socio-economic background, technical conditions and cost-benefit analysis. The cost-benefit analysis (CBA) is carried out in accordance with the Blue Book for rail transport. It consists of 4 phases:

1. Identification of variants and preparation of input data.

2. Economic analysis.

3. Financial analysis.

4. Sensitivity and risk analysis.

The economic analysis is crucial for the project, which indicates whether the project is effective from the socio-economic point of view. The analysis of economic efficiency first of all serves to justify the economic design and justification for co-financing from public funds, in particular EU funds. Economic analysis can also be a tool for selecting an investment option, which takes place if such an analysis is developed for more than one variant, usually two or three variants. This applies to situations where the investment option was not made at an earlier stage (http://eeas.europa.eu/archives/delegations/indonesia/documents/eu_indonesia/ blue_book/bb2015_en.pdf, 2015). This analysis is based on traffic forecasts, which in most cases are prepared using advanced traffic models. On the basis of forecasts, savings in time and costs are estimated, see Table 1.

Table 1. Current socio-economic benefits in investment projects

\begin{tabular}{|l|l|}
\hline time savings in passenger traffic & $\begin{array}{l}- \text { for existing train passengers, } \\
- \text { for passengers taken from other modes of transport, } \\
- \text { for passengers generated (new traffic) }\end{array}$ \\
\hline time savings in freight traffic & $\begin{array}{l}- \text { for time saving of goods, } \\
- \text { for saving time in the transport system }\end{array}$ \\
\hline savings in the rolling stock operating costs & $\begin{array}{l}- \text { for users who have previously used other modes } \\
\text { of transport, } \\
\text { for railway carriers }\end{array}$ \\
\hline savings in operating costs of lorries & \\
\hline savings in accident costs & \\
\hline savings in environmental costs & \\
\hline the costs of climate change \\
the costs of noise
\end{tabular}

Source: (Blue Book, 2015)

Clear definition of the above social benefits and costs make the analysis transparent. It is also easy to compare investments. Unfortunately, this approach excludes more complex investment projects. Problems with obtaining economic efficiency often appear in projects dedicated to the movement of goods. Wider Economic Impact is a new approach to economic analysis that can allow for a broader look at investment projects. It should be borne in mind that the neoclassical approach, strictly based on defined social benefits and costs, by definition made it impossible to carry out large investments causing general changes in the transport system. 
On the one hand, the beneficiary had the opportunity to invest large resources and seriously improve the competitiveness of its transport branch, but on the other hand, using the neoclassical CBA method, the scope of investment had to be limited to achieve economic efficiency. This problem concerns, in particular, investments in rail transport, where large capital expenditures do not mean a proportional level of expenditures increase in transported passengers and freight. This phenomenon is evident in developing countries, where road transport is a kind of civilization level. This is clearly visible in Poland. Research shows that GDP growth increases the mobility index of the society. This means that citizens of this country are increasingly traveling along with the country's development. This means mainly to an increase in the number of cars and journeys in this means of transport (Domański, 2004).

An example of sensitivity and risk analysis on the basis of CBA is the investment of HSR in Spain whose costs are too big and are decreasing Spain's GDP growth. It was not the case in China because the principle Wider Economic Impact was used to economic efficiency analysis.

The use of the neoclassical approach to CBA of investment in rail transport causes that these investments have too limited scope to achieve economic efficiency. In the case of this mode of transport, a wider perspective and the definition of other benefits are needed to make sure that significant investments are also defended in proper economic analyses.

\section{Evaluation of economic efficiency applied in the project of Pomeranian metropolitan railway construction}

Poland is also financing investment projects from the budget deficit. This results in a worsening of Poland's rating result (Miecznikowski, 2017). The preparatory phase of the project, in accordance with the Blue Book, consisted of a feasibility study. The aim of this study is to show the legitimacy of the Project regarding the construction of the Pomeranian Metropolitan Railway, including its compliance with the objectives of the Operational Program Infrastructure and Environment, strategies at the national and regional level, the optimal subsidy from the European Regional Development Fund, and the fact that the task is possible to implement, taking into account the feasibility and durability of the Project's effects.

Additionally, the feasibility study indicates the best possible technical and technological solutions, organizational, financial and economic solutions, also takes in mind ecological issues. This study justifies the selection of an option, the implementation of which will lead to the resolution of the diagnosed problems, and further defines the benefits and costs of the Project implementation, taking into account, inter alia, the following conditions:

- market needs,

- technical and technological aspects,

- organizational aspects,

- legal and environmental aspects, 
- financial and economic aspects.

The study was prepared in accordance with the recommendations formulated in the Blue Book for rail transport and other guidelines for preparing feasibility studies for Projects applying for co-financing from the Operational Program Infrastructure and Environment.

Table 2. The structure of socio-economic benefits of the Project

\begin{tabular}{|c|c|c|c|c|c|}
\hline \multirow[b]{3}{*}{ No. } & \multirow{3}{*}{\begin{tabular}{|l} 
Discount rate \\
Type of benefit
\end{tabular}} & \multicolumn{4}{|c|}{$5 \%$} \\
\hline & & \multicolumn{2}{|c|}{ Variant 1 (W3BS4) } & \multicolumn{2}{|c|}{ Variant 2 (W3BE4) } \\
\hline & & $\begin{array}{l}\text { Present value } \\
\text { [mln PLN] }\end{array}$ & Part & $\begin{array}{l}\text { Present value } \\
\text { [mln PLN] }\end{array}$ & Part \\
\hline 1 & Saving travel time & 2054 & $54.80 \%$ & 1979 & $53.63 \%$ \\
\hline 2 & Saving vehicle operating costs & 1216 & $32.43 \%$ & 1216 & $32.94 \%$ \\
\hline 3 & Saving pollution costs & 88 & $2.35 \%$ & 88 & $2.39 \%$ \\
\hline 4 & $\begin{array}{l}\text { Saving the costs of accidents } \\
\text { and their consequences }\end{array}$ & 249 & $6.65 \%$ & 249 & $6.75 \%$ \\
\hline 5 & Residual value & 142 & $3.78 \%$ & 158 & $4.28 \%$ \\
\hline 6 & Total & 3749 & $100 \%$ & 3690 & $100 \%$ \\
\hline
\end{tabular}

Source: (Feasibility Study of the Pomeranian Metropolitan Railway project, 2012)

Applied socio-economic benefits and economic effectiveness indicators of economic validity of the investment qualified it for co-financing from the EU funds.

The results of the effectiveness analysis are presented in Table 3.

Table 3. The results of the effectiveness analysis

\begin{tabular}{|c|l|r|r|}
\cline { 2 - 4 } \multicolumn{1}{c|}{} & Discount rate & \multicolumn{2}{c|}{$5 \%$} \\
\hline No. & & Variant 1 (W3BS4) & Variant 2 (W3BE4) \\
\hline 1 & ENPV & 2435991891 PLN & 2237611615 PLN \\
\hline 2 & B/C Ratio & 3,08 & 2,73 \\
\hline 3 & EIRR & $21,93 \%$ & $19,53 \%$ \\
\hline
\end{tabular}

Source: (Feasibility Study of the Pomeranian Metropolitan Railway project, 2012)

An opportunity for the implementation of investments in the field that matches the level of economic development and allowing for the development and competitiveness of the economy may be Wider Economic Impact. It is a method of examining economic efficiency in a way that takes into account the multifaceted nature of an investment. Mainly this method in addition to standard socio-economic benefits contained in the CBA method takes into account the measurement of service quality. In addition, this method takes into account the fact that investments can give an additional impulse to economic development. This method does not close in forecasts of economic development, which is not assumed that the investment process will directly affect the results of these forecasts. The CBA method requires the development of traffic forecasts closed as a part of economic growth and GDP growth indicators developed historically. What if the investment and the whole investment process will affect even faster economic growth? Unfortunately, this will affect the failure to achieve economic efficiency and the need to limit the scope 
of investment and even to cease investment. The use of the Wider Economic Impact method in the investment planning and preparation process allows the following indicators to be used in addition to the CBA benefits mentioned above:

- Agglomeration effects,

- Increased competitiveness,

- Output + imperfect market,

- Additional demand for work.

These indicators give much greater opportunities to create an investment process. In the case of rail transport WEI method gives the possibility to go beyond the existing network and allows the construction of new railway lines. The construction of a new railway infrastructure allows for a stronger competitive position of this mean of transport.

\section{Attempt of comparative study of the financing of Pomeranian metropolitan railway construction project with the most inhibited projects in far East Asia}

In recent years, the number of investments in the agglomeration railway infrastructure has risen sharply. This applies to both completed and ongoing investments. The fastest development of the agglomeration railway took place in China, where city railway systems were built or expanded in 23 cities in the years 2004-2014. Investments were possible to carry out, mainly thanks to the PPP formula, which in urban areas gives particularly great benefits. With the increase in rail urban transport, PPPs in their construction and operation have been used in the last two decades. This was due to the fact that investments in urban rail transport were very capital-intensive, and the use of the private sector in the provision of services was necessary (Chang, 2013).

The main distinctive feature of the PPP financing model is the possibility of realizing the investment in isolation from the possibility of financing the public beneficiary who is the manager of the railway infrastructure.

East Asian cities (and countries) differ from most western cities in size of metropolitan areas and population densities. The capital and large cities of East Asia typically have populations well above 5 million, high population densities, motor restrictions measures in place, and high proportion of trips made by public transport. Public transport mode shares in Hong Kong, Singapore, Seoul and Tokyo are in excess of 50 percent (Choi and Loh, 2013).

These characteristics are favourable for large scale implications for urban rail transport operations. In this section three distinctive features of East Asia urban rail transport should be discussed. They differ from those in most U.S. and European cities: high farebox recovery, successful land value capture and vertical structure of urban rail transit companies (Chang, 2013).

Fare revenue and fare elasticity of demand are important for urban rail transit sustainability. The way fares are structured and adjusted affect transit demand, quality of transit services, profitability, as well as subsidies required for the system. 
The difference between operating costs of rail and passenger fare revenues, ranges from 29 to 89 percent for the U.S. urban rail transit systems (Parry, 2009).

Land Value Capture (LVC) plays an important role in financing urban transit development and operations. The idea of land value capture dates back to Ricardo (1821) with George (1879) being the strongest advocates. The demand for a particular plot of land is derived from its facilitation of economic activities. Land value is not only determined by its intrinsic value or original productivity, but also by other factors including population and economic growth, investment in infrastructure and local services, as well as land use regulations. Land user planners can increase land value by allowing a change in land use or permitting an increase in density (plot ratio or floor area ratio FAR). Governments can increase land value by investing in infrastructure, providing local services or improving local amenities.

To help public sector investment in local infrastructure and other amenities government can use LVC which can be broadly classified. To help finance public sector investment in local infrastructure and other amenities, governments can use LVC instruments which can be broadly classified into either tax or free based or development-based. The tax or free based category captures the increment financing. The property tax is one of the most important revenue sources for most developed countries. In the late nineteenth century George (1879) had argued that as investment in public goods can increase the aggregate land value is not efficient but also the only tax necessary to finance public expenditure (George single tax proposal). Although George's original land tax proposal was flawed, the merits of the property tax are well recognised by economists (Friedman, 1978; Stiglitz, 1977). Property taxes can be introduced or increased to find local infrastructure and services with minimal distortions to the land market. The disadvantage however is the fact that most property tax systems do not have clear links between infrastructure and public service improvements are often opposed by those effected.

Part of the investment in railway infrastructure in Poland could be carried out on the basis of the PPP financing formula. This mainly applies to investments in urbanized areas with dense development and high industrial potential, such as potential in Central Europe. This is due to the fact that it is difficult to find space for investments in these areas, and, on the other hand, part of this area is occupied by rail infrastructure that needs capital. Therefore, merging into a partnership is the best solution, because the investor gains necessary space, and the railway infrastructure financing possibilities.

Taking into account railway infrastructure in Poland, the PPP financing formula is for now only applicable in the case of the station redevelopment investment and point infrastructure. Such investments have been carried out in several cities, e.g. in Sopot.

Using this formula in the aspect of linear infrastructure projects could bring greater benefits. The partnership of the infrastructure manager, local self-government and private investors on the PKM line could result in a much larger financial potential that would result in the implementation of the investment without any stages. The contribution of the city, developers and asset management funds would result in relieving the infrastructure manager from the costs of constructing stations 
and passenger stops, which could result, among others, in additional funds for electrification and additional infrastructure assets to increase traffic flow.

In the case of large infrastructure investments, China is an important partner and investor. The stock of Chinese investment in Europe is low compared with America's or Japan's, but it is shooting up. According to one study, in 2016 its new FDI in the EU was over $77 \%$ above that of the year before, at $35 \mathrm{bn}(\$ 41 \mathrm{bn})$. Nowadays China's focus on the innovation hubs of northern Europe as much as on infrastructure, but crisis-hit southern Europe economies have also lapped up its lucre, especially those that have had to divest state assets under euro-zone bail-outs. Last year Cosco, a Chinese state-owned shipping firm, acquired a controlling stake in in the main Greek port of Piraeus, providing Chinese maritime goods exporters with a European foothold. Portugal is rolling in Chinese loot.

But the latest front is further east. This week Ki Keqiang, China's prime minister, swooped in to Budapest for the annual meeting of the snappily title Co-operation Between China and Central and Eastern European Countries (colloquially knows as the $16+1$ format), bringing promises worth $3 \mathrm{bn}$. There is talk of investment in Estonian dairy, Slovakian freight and high-speed rail link from Serbia to Hungary (which may violate EU tendering rules). Poland's former prime minister in the years 2015-2017, grumbled about Chinese red tape, but actually Hungary's prime minister was more effusive, celebrating China's economic heft and its agreeable habit of not talking about democracy or human rights (Charlemagne. More than yuan Europe, 2017).

Currently, China is investing in large enterprises in Central and Eastern Europe. One of such investments is the construction of a new high-speed railway line from Budapest to Belgrade. The investment consists in the construction of a new two-track and electrified railway line connecting the capital of these countries.

The use of a different financing formula, as well as an analysis of economic effectiveness based on the Wider Economic Impact theory, would allow for better investment preparation. The project, as part of the study analyses, not only of the aspect of transport economics, but also the impact of investments on the local economy, as well as the potential for improvement investors would bring a different dimension of investing in the railway infrastructure network.

\section{Conslusions}

The investment of the Pomeranian Metropolitan Railway construction project continues. The first stage, including the construction of an un-electrified railway line with a stations and passenger stop infrastructure, is already insufficient. Diesel traction is characterized by a small capacity of vehicles. In addition, the mountain profile of the railway line makes it difficult to use with its operating parameters. Only in the second stage, whose implementation will take place in 2020-2023, the line will be electrified and better connected with the railway network of Pomerania. However, it will still be necessary to further develop interchanges and other transport infrastructure of the region. 
The program of expansion of railway infrastructure and other public transport in the European Union programming is burdened with a high risk of lack of complementarity and network connectivity. This is due to the selection criteria and pre-allocated financial resources. Also, predetermined, limited by the Blue Book, economic benefits that are used to determine the economic effectiveness of the project limit the financial possibilities of the investment and thus impoverish their scope. If a broad view of the economic aspects of the project and wide financing options were applied, the scope of the project could be extended. A rigid view of co-financing from the European Union is the only source of investment financing. The solution would be to use financing by many entities - PPP or looking for a large partner on the global market, which is undoubtedly China.

Using one of the above formulas would allow for the implementation of the entire investment without having to be phased in, which would increase the competitiveness of rail transport and, consequently, a more effective implementation of the transport policy of the European Union, Poland and its Pomeranian region.

\section{References}

Blue Book (2015), http://eeas.europa.eu/archives/delegations/indonesia/documents/eu_indonesia/blue_book/bb2015_en.pdf, pp. 12, 80.

Chang, Z. (2017), Urban rail transport PPP's lessons from East Asian cities. Transportation Research, 105, pp. 106-107, 113-114.

Charlemagne. More than yuan Europe (2017), The Economist, 02.12.2017.

Chinese finance stormy weather (2017), The Economist, 2-8.12.2017.

Choi, C.C., Loh, N. (2013), Transport policies and patterns a comparison of five Asia cities Journeys.

Communist Party congress: How China picks its leaders. BBC News, 05.10.2017. Available from http://www.bbc.com/news/world-asia-china-41250273 [Accessed 15 October 2017].

Disaster management (2017), The Economist, 09.12.2017.

Domański, H. (2004), O ruchliwości społecznej w Polsce. Henryk Domański \& Wydawnictwo IFiS PAN, p. 136.

Drucker, P. (1993), Managing in Turbulent Times, New York, Harper \& Row.

Feasibility Study of the Pomeranian Metropolitan Railway project. (2012). Available from http:// www.pkm-sa.pl/glowna/wp-content/uploads/2010/09/DSC-Aktualizacja-Studiu m-Wykonalno\% C5\% 9Bci-06.03.2012.pdf [Accessed 10 November 2017], pp. 229-230.

Friedman, M. (1978), An interview with Milton Friedman. Human Event.

George, H. (1879), Progress and Poverty: An Inquiry into the Cause of Industrially Depressions and of Increase of Want with Increase of Wealth: The Remedy. Doubleday Garden City New York.

https://www.bloomberg.com/news/articles/2017-07-20/panda-diplomacy-masks-doubts-i n-europe-over-china-s-sincerity [Accessed 16.12.2017].

IMF warns of 'vulnerabilities' that could derail global recovery (2017), Financial Times, 11.10.2017. International investors chase the red dragon (2017), Financial Times, 11.12.2017.

Kołodko, G. (2008), Wędrujący Świat, Wyd. Prószyński i Spółka, Warszawa, p. 155.

Miecznikowski, S. (2017), Limits nad risk of developing transport infrastructure in Poland,. Journal of European Economy, 16.

National Railway Program up to 2023 (Krajowy Program Kolejowy do 2023 roku). (2016). Available from http://mib.bip.gov.pl/fobjects/download/194387 [Accessed 15 November 2017].

Parry, L., Small, K. (2009), Should urban transit subsidies be reduced?, American Economy Review, 62 (4), pp. 604-691.

Rachman, G. (2017), China's bold challenge to the west, Financial Times, 24.10.2017, p. 9. 
Refinance push China's ethical bond issuance takes it to top spot in world green paper league (2017), Financial Times, 11.12.2017.

Ricardo, D. (1821) On the principles of political economy and taxation, Third edition, John Murray, London.

Stiglitz, I.E. (1977) The theory of local public goods. In Feldstein 38 (46). The economics of Public Services. Macmillan Press London.

Sun, L., Huang, Y., Chen, Y., Yao, L., Vulnerability assessment of urban rail transit based on multi-static weighted method in Beijing, China, Transportation Research. 108, p. 12.

Wang, H., Wu, J. (2018), Global investors can ill afford to ignore Chinese equities, Financial Times, 15.01.2018, p. 9 .

Wobbling into the WTO (2017), The Economist, 02.12.2017.

\section{Corresponding authors}

Stanisław Miecznikowski can be contacted at: stanmiecznik@gmail.com

Tomasz Radzikowski can be contacted at: tom.radzikowski@gmail.com 